\title{
About the properties of ash-filled concrete and JV GLENIUMSKY 504
}

\author{
Ulugbek Abdullaev*, and Urinbek Turgunbaev \\ Tashkent State Transport University, Tashkent, Uzbekistan
}

\begin{abstract}
Due to the complex use of a filler from industrial waste in concrete technology, a complex solution to the problems of monolithic concrete technology, including the chemicalization of concrete, chemical additives of polyfunctional action, it is possible to significantly influence the properties of concrete mixture and concrete.
\end{abstract}

\section{Introduction}

All over the world, the annual rise in prices for building materials and structures significantly increases the cost of erection of buildings and structures. It is relevant to obtain effective concrete for monolithic structures of buildings using waste from local industry. As the studies have shown, to save cement, it is possible to use fly ash from the Novoangrenskaya TPP, slag wastes from the Almalyk Mining, and Metallurgical Combine (AGMK) slags from the Bekabad Metallurgical Combine, and steel-making slags from APO Uzmetkombinat $[4,5,6,9,13]$. To increase concrete strength and performance properties, the use of super or superplasticizers is effective $[1,2,10,11,16]$. Abroad, super and superplasticizers have been developed and produced, which, when introduced into a concrete mixture, increase its workability and compaction and contribute to an increase in the strength, frost resistance, and water resistance of concrete. In Germany, the BASF company produces special additives for ready-mixed concrete RHEOBUILD $716 \mathrm{~K}$, POZZOLITH 550 HE, RHEOBUILD $1000 \mathrm{~K}$, MELMENTL10/33, POZZOLITH 42CF, RHEOMAC 701. According to data published in the foreign press, these joint ventures have a strong thinning effect, not accompanied by a decrease in concrete strength. The aim of the study is to obtain efficient concrete using waste from local industries.

\section{Methods}

To study the physical and mechanical properties of concrete, we first carried out a number of experimental studies at the micro-level. Complex additive GLENIUMSKY 504 is used to prepare concrete mixtures of any class and for any purpose, especially monolithic structures of various operating conditions. Due to the ability to increase the mobility of concrete and mortar mixtures, the GLENIUMSKY 504 additive in an optimal amount improves not only the physical and mechanical properties of concretes and mortars but also

\footnotetext{
*Corresponding author: 1658781azizbek@gmail.com
} 
the rheological properties of the cement system and concrete mixture, as well as increases the economic performance of production, reduces the metal and energy consumption, and decreases labor costs $[3,7,8,14,15$,]. In some cases, working conditions are improved due to the elimination or reduction of the use of vibration installations.

An important circumstance of using the additive is the possibility of reducing the consumption of cement while maintaining, and in some cases, improving, the properties of concrete and mortar mixtures and hardened concrete.

In a market economy, when the cost has risen sharply, the use of the GLENIUMSKY 504 additive becomes an economically profitable method for regulating the cost of monolithic concrete.

\section{Results and Discussion}

Experimental studies were carried out on cement mixtures, and the normal density of the control cement paste without and with additive was determined, the results of which are given in table 1.1. As a result, it was determined that with the introduction of JV GLENIUMSKY 504 into the cement paste, the water-cement ratio sharply decreases. This is due to the formation of adsorption layers around the cement particles by the molecules of PC SP GLENIUMSKY 504 and a decrease in the surface tension of water, thereby increasing the plasticizing effect with a decrease in water demand by $8-29 \%$.

Table 1. Effect of the dosage of GLENIUMSKY 504 on the normal thickness of the cement paste

\begin{tabular}{|c|c|c|c|c|c|c|}
\hline 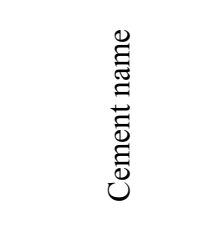 & 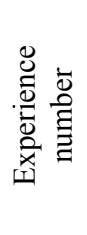 & 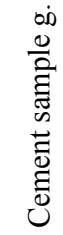 & 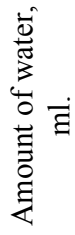 & 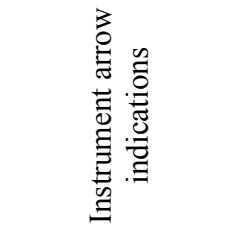 & 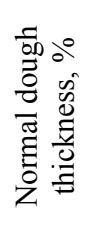 & 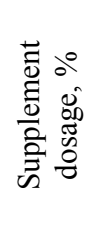 \\
\hline \multirow{5}{*}{$\begin{array}{c}\text { Portland cement } \\
\text { Akhangaran } \\
\text { stamps } 400\end{array}$} & 1 & 400 & 104 & $\begin{array}{l}7 \mathrm{~mm} \text { does not } \\
\text { reach the bottom }\end{array}$ & 26 & 0 \\
\hline & 2 & 400 & 96 & $\begin{array}{l}6 \mathrm{~mm} \text { does not } \\
\text { reach the bottom }\end{array}$ & 24 & 0.6 \\
\hline & 3 & 400 & 88 & $\begin{array}{l}6 \mathrm{~mm} \text { does not } \\
\text { reach the bottom }\end{array}$ & 22 & 0.8 \\
\hline & 4 & 400 & 76 & $\begin{array}{l}7 \mathrm{~mm} \text { does not } \\
\text { reach the bottom }\end{array}$ & 19 & 1.0 \\
\hline & 5 & 400 & 75 & $\begin{array}{l}7 \mathrm{~mm} \text { does not } \\
\text { reach the bottom }\end{array}$ & 18,5 & 1.2 \\
\hline
\end{tabular}

Table 1 shows that JV content of 504-1 \% GLENIUMSKY reduces water demand by $29 \%$, and content of more than $1 \%$ does not significantly affect the NG of cement paste.

The dough of normal density with PC JV GLENIUMSKY 504 content-1\% is molded into cubes with a size of $2 \times 2 \times 2 \mathrm{~cm}$, after which their strength is determined on a hydraulic press. The test results are shown in Figure 1.1. The strength of specimens $2 \times 2 \times 2 \mathrm{~cm}$ in size after 28 days increases from 40 to $78 \mathrm{MPa}$.

Since GLENIUMSKY $504 \mathrm{JV}$ molecules are adsorbed on the surface particles of cement grains and impart a negative charge to them, the adsorption films formed by them are permeable to water. This has a positive effect on the processes of hydration and hardening of cement [5]. This is also due to the adsorption phenomena arising from the peculiarities of the interaction of molecules of SP GLENIUMSKY 504 with the main centers on the surface of the particles of the dispersed phase. Thus, the optimal number of 
JV GLENIUMSKY 504 was determined, which was taken equal to $1 \%$.

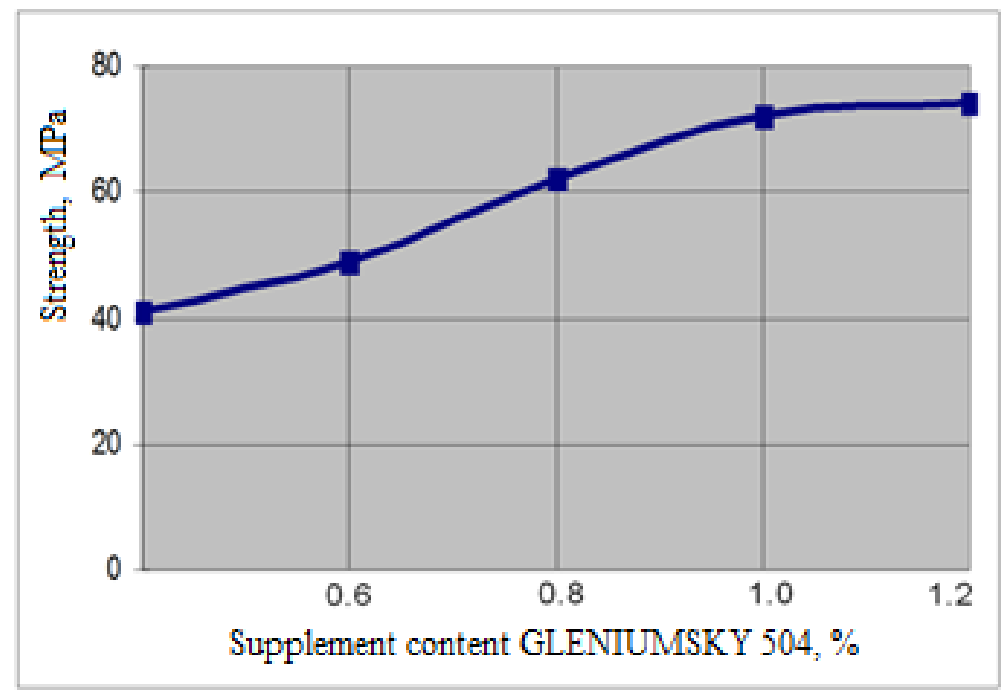

Fig. 1. Compressive strength of cement stone versus SP content

As shown earlier [17], GLENIUMSKY $504 \mathrm{JV}$ molecules are adsorbed on the main centers of cement particles and form strong hydrogen and donor-acceptor chemical bonds. GLENIUMSKY $504 \mathrm{JV}$ forms physical bonds with the surface of acid filler particles (fly ash). Since the hydrogen bond can be easily broken in an aqueous suspension and easily exchanged for water molecules, there should be no slowdown in the processes of hydration and hardening of filled cement with additives SP GLENIUMSKY 504.

The need to use the fly ash mineral filler to obtain monolithic concrete is dictated by technical, economic, and environmental considerations. Based on this, it seems appropriate to consider the prerequisites for using local fillers to obtain monolithic concrete using JV GLENIUMSKY 504. The following factors will influence the choice of filler for monolithic concrete.

1. Economic. Minimization of cement consumption due to the constant rise in prices for energy resources and cement.

2. Technical. Maximizing the potential activity of Portland cement and improving its properties.

3. Environmental. Environmental protection through the use of industrial and power waste.

Justification and choice of filler, taking into account the listed factors, should be made based on the intended purpose of monolithic concrete. In our opinion, to obtain monolithic concrete, to minimize the consumption of cement and its overall efficiency, it is advisable to use fly ash as a filler. From previously performed works $[9,6]$, each type of filler, including fly ash, must have a certain specific surface area that provides the maximum technical effect from the use in cement material.

In monolithic concrete, depending on the purpose, the filler content should be determined from the condition of the need to achieve the required strength. The role of the polymer additive, in this case, is more complicated. Thickened multilayer adsorption films in the coagulation period play the role of surfactants, and in the crystallization period - a dense (low-permeable) adsorption film around hydrated formations that increase the strength of cement materials due to the chemical interaction of the polar groups of the additive with both cement hydration products and active centers on the surface of filler 
particles.

The latter's presence determines the possibility of reactions in which a chemical, covalent, and coordination bond can be formed due to the $\mathrm{CO}$ group. In addition, in cement materials, hydroxyl and carbonyl groups can interact with each other and functional groups of cement and filler during curing. So the $\mathrm{OH}$ group can take part in chemical interaction with such components of the fly ash filler as $\mathrm{SiO} 2, \mathrm{CaO}, \mathrm{MgO}$.

Table 2. Influence of fly ash dosage on normal cement paste density

\begin{tabular}{|c|c|c|c|c|c|c|}
\hline Cement name & 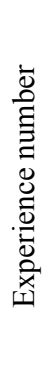 & 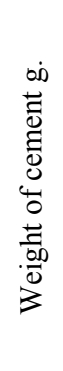 & 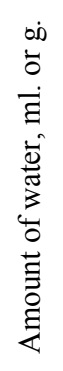 & 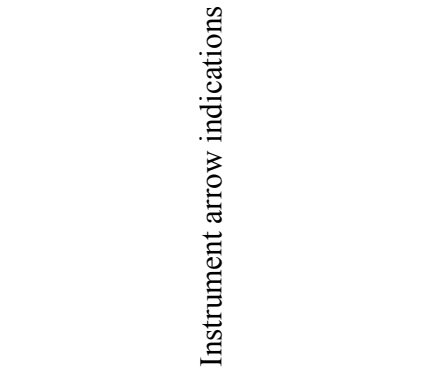 & 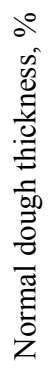 & 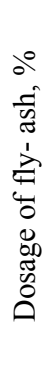 \\
\hline \multirow{6}{*}{$\begin{array}{c}\text { Portland cement } \\
\text { Akhangaran stamps } \\
400 \text { D20 }\end{array}$} & 1 & 400 & 104 & $7 \mathrm{~mm}$ does not reach the bottom & 26 & 0 \\
\hline & 2 & 360 & 108 & $6 \mathrm{~mm}$ does not reach the bottom & 27 & 10 \\
\hline & 3 & 320 & 112 & $6 \mathrm{~mm}$ does not reach the bottom & 28 & 20 \\
\hline & 4 & 280 & 124 & $7 \mathrm{~mm}$ does not reach the bottom & 30 & 30 \\
\hline & 5 & 240 & 132 & $7 \mathrm{~mm}$ does not reach the bottom & 33 & 40 \\
\hline & 6 & 200 & 140 & $6 \mathrm{~mm}$ does not reach the bottom & 36 & 50 \\
\hline
\end{tabular}

Based on this, we carried out experimental studies to determine the effect of fly ash on the water demand and strength of cement stone. The research results are shown in Table 2.

Analysis of the data obtained (table 2) indicates that with an increase in the dosage of fly ash, an increase in water demand is observed at a normal density of the cement paste. Especially when the content of fly ash is $30 \%$ or more, there is a significantly high water demand, which negatively affects the strength of the cement stone. The dispersion of fly ash also has a noticeable effect on the water requirement of the binder. So, with an increase in the dispersion of fly ash from 250 to $350 \mathrm{~m}^{2} / \mathrm{kg}$ with the same fly ash content of $20 \%$, the water demand of the filled cement binder increases.

The efficiency of using mineral fillers in cement compositions can be significantly increased by chemical additives on their surface [20]. The use of filler combined with the activation of the binder in the mixer opens up new possibilities for obtaining highly filled concrete.

Table 3. Water demand of cement paste with ash filler and additive JV GLENIUMSKY 504.

\begin{tabular}{|c|c|c|c|c|c|c|c|c|c|}
\hline \multirow{2}{*}{$\begin{array}{c}\text { Fly ash } \\
\text { content, \% }\end{array}$} & \multicolumn{10}{|c|}{ Dispersion of fly ash, $\mathrm{cm}^{2} / \mathrm{kg}$} \\
\cline { 2 - 11 } & \multicolumn{3}{|c|}{250} & \multicolumn{3}{|c|}{300} & \multicolumn{3}{|c|}{350} \\
\hline & 0.8 & 1.0 & 1.2 & 0.8 & 1.0 & 1.2 & 0.8 & 1.0 & 1.2 \\
\hline 10 & 22.5 & 20.0 & 19.0 & 22.0 & 19.0 & 18.0 & 23.0 & 21.5 & 20.0 \\
\hline 20 & 24.5 & 21.5 & 20.5 & 23.5 & 20.5 & 19.5 & 25.0 & 23.0 & 22.0 \\
\hline 30 & 25.0 & 22.5 & 21.5 & 24.0 & 21.0 & 20.5 & 26.0 & 24.0 & 23.0 \\
\hline 40 & 27.5 & 24.0 & 23.0 & 26.5 & 23.5 & 22.0 & 26.0 & 26.5 & 25.5 \\
\hline 50 & 29.5 & 26.5 & 25.5 & 28.0 & 24.5 & 23.5 & 31.5 & 30.0 & 28.5 \\
\hline
\end{tabular}

It should be noted that when the fly ash content is up to $20 \%$, the water demand of the composition does not change so noticeably, and only at a filling degree of $20 \%$, a sharp 
increase in the mixing water begins (table 3.).

The observed effect can be explained from the standpoint of the polystructural theory of composite materials - the dilution of the binder with a finely dispersed mineral filler at certain optimal levels improves the properties of systems [21]. The content of JV GLENIUMSKY 504, introduced into the binder on the surface of the ash filler, also has a significant effect on the water demand of the ash-cement dough. As can be seen from the graphical dependencies, Within the dosage of the additive SP GLENIUMSKY 504 to 1.0 $\%$, the decrease in the water demand of the binder is very significant and amounts to $20-25$ $\%$.

When $20 \%$ of fly ash is introduced into the cement system, the hydration process occurs more intensively at all observation periods. Obviously, the acceleration of the hydration process occurs due to the larger specific surface of fly ash, as well as the peptizing effect of the additive SP GLENIUMSKY 504 on the binder component, especially on finely ground ash particles, and, as a result of this more intensive filling in the initial period of hydration of highly dispersed hydrosilicates. In addition, a decrease in the water demand of cement paste with fly ash leads to the convergence of particles of the neoplasm, which determines their high binding capacity.

The study of the strength of filled cement binders was carried out on samples - cubes with a size of $2 \times 2 \times 2 \mathrm{~cm}$ with a fixed spread of a microcone from $85 \pm 2 \mathrm{~cm}$. The dosage of the additive SP GLENIUMSKY 504 was from 0.8-1.2 \%. The compressive strength of the cement stone was determined at the age of 28 days of normal hardening and at one day of age.

The analysis of the obtained dependences shows that with an increase in the degree of filling from $10 \%$ to $20 \%$, an increase in the strength of the cement stone is observed, with the exception of its slight decline in the region of $20 \%$ filling, with normal hardening. This, in our opinion, is associated with the formation of the binder with an optimally dispersed structure, which, considered in the filling interval, increases continuously since the cement particles $\mathrm{Ssp}=250 \mathrm{~m}^{2} / \mathrm{kg}$ are replaced by a more dispersed one with $\mathrm{S}_{\mathrm{sp}}=300 \mathrm{~m}^{2} / \mathrm{kg}$. Thus, we can conclude that the optimal degree of filling of the cement binder is in the range of $10-30 \%$ of the content of the hall. It should be noted that the strength of a filled cement stone at $\mathrm{CV}=20 \%$ exceeds that of an unfilled stone by $15-25 \%$. The data obtained confirm the point of view of PA Rebinder [19, 20], who asserted that the strength after crystalline intergrowth does not depend on the indicators of a particular hydration formation but depends, first of all, on the strength of the crystallization dispersed structure. This also confirms the hypothesis about the role of the mineral filler as a structure-forming element in filled cement systems [9]. Depending on the influence of the dispersion of fly ash and the content of JV GLENIUMSKY 504 on the strength of the filled cement stone (Fig. 1.2. And 1.3.), They also have a curvilinear character with a pronounced extreme maximum. They can be used to easily determine the areas of optimal values of ash dispersion - fly ash and the content of JV GLENIUMSKY 504, necessary to optimize the composition of the filled binder. This area for the dispersion of the filler corresponds to $250-350 \mathrm{~m}^{2} / \mathrm{kg}$, and the additives of the JV GLENIUMSKY 504 - from 0.8 to $1.2 \%$. 


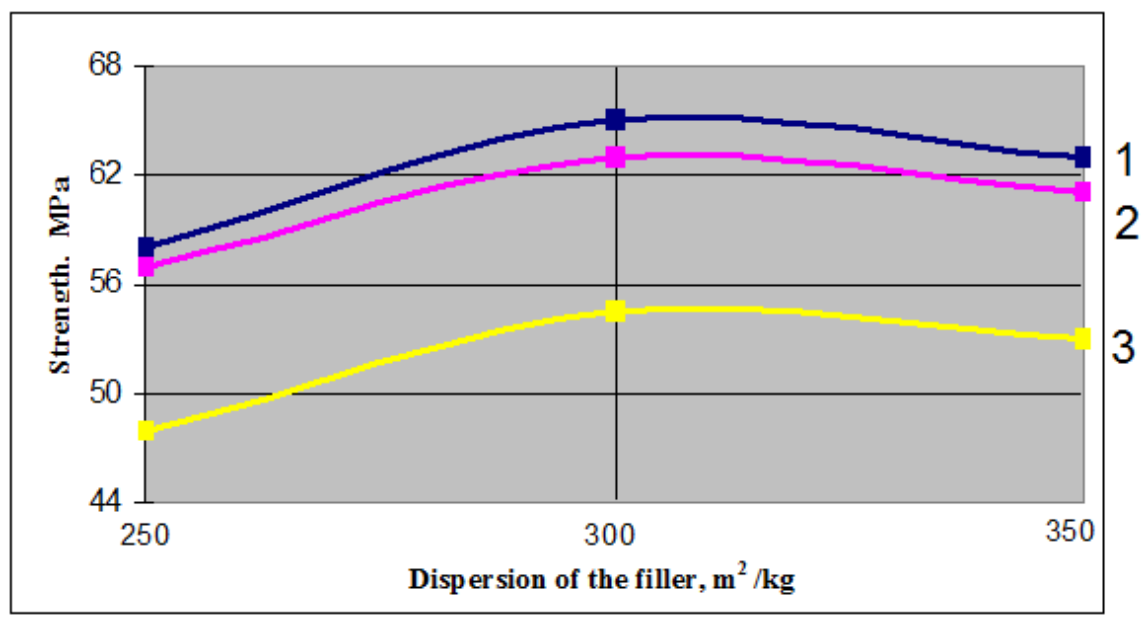

Fig. 2. The influence of the dispersion of fly ash on the strength of the filled cement stone with $\mathrm{Cv}=$ $20 \% 1,2,3$ are fly ash with the content of JV GLENIUMSKY 504, respectively $0.8 ; 1.0 ; 1,2 \%$

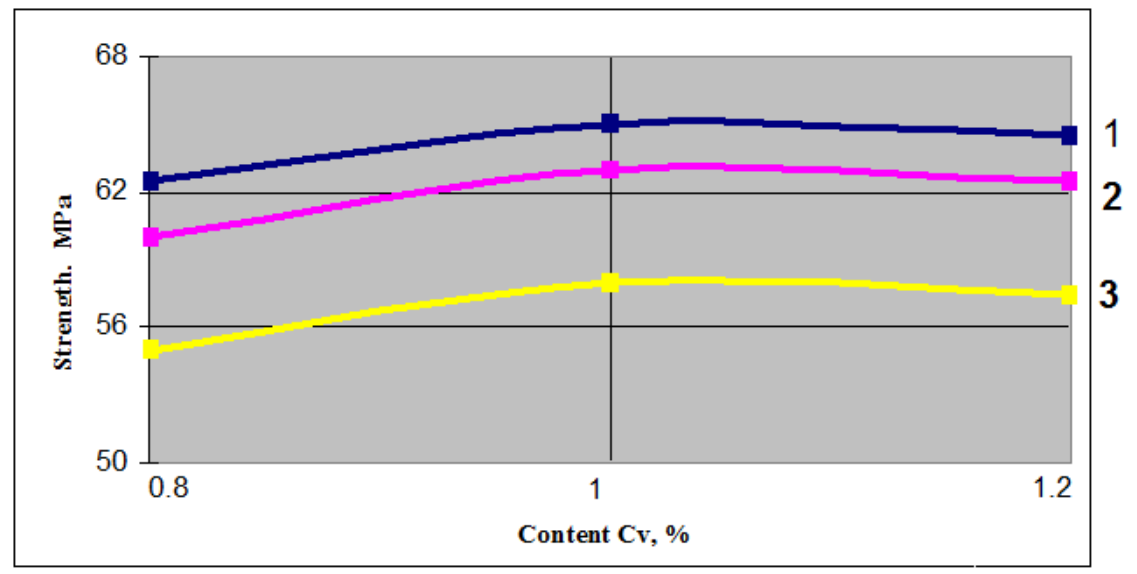

Fig. 3. Influence of JV GLENIUMSKY 504 on the strength of cement stone with fly ash $\mathrm{Cv}=20 \%$ : $1,2,3$ are for fly ash with dispersion, respectively $250,300,350$

From a set of technological factors that significantly affect the properties of concrete mixes and concretes obtained by conventional technology, we have investigated: the sequence of loading the binder components. Experimental studies were carried out on concrete compositions of class B15,20, and 30, adjusted by the introduction of fly ash and JV GLENIUMSKY 504 (Table 4.).

Table 4. Adjusted concrete compositions

\begin{tabular}{|c|c|c|c|c|c|c|c|}
\hline \multirow{2}{*}{ Concrete class } & \multirow{2}{*}{ Cone draft, $\mathrm{cm}$} & $\mathrm{W} / \mathrm{C}$ & \multicolumn{5}{|c|}{ Material consumption for $1 \mathrm{~m}^{3}$ concrete, $\mathrm{kg}$} \\
\cline { 3 - 8 } & & $\mathrm{C}+\mathrm{N}$ & cement & filler & sand & rubble & $\mathrm{W}+\mathrm{A}$ \\
\hline B15 & $16-20$ & 0.46 & 224 & 56 & 664 & 1300 & 130 \\
\hline B20 & $16-20$ & 0.42 & 264 & 66 & 620 & 1200 & 140 \\
\hline B30 & $16-20$ & 0.33 & 368 & 92 & 590 & 1150 & 155 \\
\hline
\end{tabular}

To establish the influence of the sequence of loading the components on the concrete mixture and concrete properties, we have chosen options for the loading scheme. Considering this, as well as the fact that cement $(\mathrm{C})$, ash filler $(\mathrm{F})$, sand $(\mathrm{P})$, water with an 
additive (VsD) should be supplied, the following options for the loading scheme were taken into consideration:

1) $\mathrm{R}+\mathrm{S}+\mathrm{F}+\mathrm{C}+\mathrm{VsD}$;
2) $\mathrm{R}+\mathrm{C}+\mathrm{F}+\mathrm{S}+\mathrm{VsD}$;
3) $\mathrm{S}+\mathrm{C}+\mathrm{R}+\mathrm{F}+\mathrm{VsD}$;
4) $\mathrm{S}+\mathrm{C}+\mathrm{R}+\mathrm{VsD}+\mathrm{F}$.

Mixing takes place manually. In the research process, we studied the most important technological properties of the concrete mixture: mobility and vibration formability. The concrete strength was determined at the age of 28 days of normal hardening. The results of studies of the properties of optimally filled concrete mixes and concretes with various combinations of loading components are shown in Table 1.5.

The results show that the first loading scheme is rational $(\mathrm{S}+\mathrm{C}+\mathrm{F}+\mathrm{R}+\mathrm{W}+\mathrm{A})$, allowing obtaining concrete mixtures with improved vibration formability and providing high concrete strength. At the same time, the increase in concrete strength relative to other loading schemes is greater 6-8 \%.

Table 5. Influence of the loading sequence on the properties of concrete mix and concrete

\begin{tabular}{|c|c|c|c|c|}
\hline \multirow[b]{2}{*}{$\begin{array}{l}\text { Concrete } \\
\text { class }\end{array}$} & \multirow{2}{*}{$\begin{array}{l}\text { Mixer loading } \\
\text { sequence }\end{array}$} & \multirow[b]{2}{*}{$\begin{array}{c}\text { Cone } \\
\text { draft, } \mathrm{cm}\end{array}$} & \multicolumn{2}{|c|}{ Compressive strength of concrete, $\mathrm{MPa}$} \\
\hline & & & $\begin{array}{l}\text { At the age of } 28 \text { days } \\
\text { of normal hardening }\end{array}$ & At day-old \\
\hline \multirow{4}{*}{ B15 } & $\mathrm{R}+\mathrm{S}+\mathrm{F}+\mathrm{C}+\mathrm{VsD}$ & 22 & 30.0 & 19.6 \\
\hline & $\mathrm{R}+\mathrm{C}+\mathrm{F}+\mathrm{S}+\mathrm{VsD}$ & 22 & 27.5 & 17.5 \\
\hline & $\mathrm{S}+\mathrm{C}+\mathrm{R}+\mathrm{F}+\mathrm{VsD}$ & 22 & 27.0 & 16.9 \\
\hline & $\mathrm{S}+\mathrm{C}+\mathrm{R}+\mathrm{VsD}+\mathrm{F}$ & 22 & 26.0 & 16.4 \\
\hline \multirow{4}{*}{ B20 } & $\mathrm{R}+\mathrm{S}+\mathrm{F}+\mathrm{C}+\mathrm{VsD}$ & 20 & 37.0 & 26.9 \\
\hline & $\mathrm{R}+\mathrm{C}+\mathrm{F}+\mathrm{S}+\mathrm{VsD}$ & 20 & 34.0 & 24.6 \\
\hline & $\mathrm{S}+\mathrm{C}+\mathrm{R}+\mathrm{F}+\mathrm{VsD}$ & 20 & 33.0 & 24.0 \\
\hline & $\mathrm{S}+\mathrm{C}+\mathrm{R}+\mathrm{VsD}+\mathrm{F}$ & 20 & 32.0 & 23.1 \\
\hline \multirow{4}{*}{$\mathrm{B} 30$} & $\mathrm{R}+\mathrm{S}+\mathrm{F}+\mathrm{C}+\mathrm{VsD}$ & 16 & 55.5 & 40.6 \\
\hline & $\mathrm{R}+\mathrm{C}+\mathrm{F}+\mathrm{S}+\mathrm{VsD}$ & 16 & 51.0 & 37.0 \\
\hline & $\mathrm{S}+\mathrm{C}+\mathrm{R}+\mathrm{F}+\mathrm{VsD}$ & 16 & 50.0 & 36.1 \\
\hline & $\mathrm{S}+\mathrm{C}+\mathrm{R}+\mathrm{VsD}+\mathrm{F}$ & 16 & 48.2 & 35.8 \\
\hline
\end{tabular}

Thus, from the studies carried out, it can be concluded that the rational scheme for loading a component of a concrete mixture with ash and JV GLENIUMSKY 504 are: the sequence of loading components according to the scheme "crushed stone + sand + filler + cement + water with the additive."

\section{Conclusions}

1. The positive effect of the ash filler and JV GLENIUMSKY504 on the physical and mechanical characteristics of the cement binder has been established.

2. The high efficiency of the combined use of fly ash and JV GLENIUMSKY504 has been shown, which allows to reduce the water demand of the binder by $20-25 \%$, to achieve an increase in the strength of cement stone with a degree of filling (CV $=20 \%)$ by $11-20 \%$.

3. A rational sequence of the introduction of components in a concrete mixture with an ash filler and an additive SP GLENIUMSKY504 has been determined, which ensures the production of a concrete mixture and concrete with the best rheological and physical, and technical properties. It is shown that the best results are achieved with the introduction of components according to the scheme "crushed stone + sand + filler + cement + water with the additive." 


\section{References}

1. State, prospects for the development and use of chemical additives in the conditions of Uzbekistan, Report Republic of meetings, p.103, May 3-4, Tashkent, (1982)

2. Ivanov F.M., Batrakov V.G., Lagaida A.V. The main directions of application of chemical additives to concrete // Concrete and reinforced concrete, 9. pp. 3-5, (1981)

3. Batrakov V.G.: Superplasticizer thinner SMF, Concrete and reinforced concrete 5, pp. 18-20, (1985)

4. Babaev Sh.T. Effective use of TPP ash and technology of high-strength concrete with the addition of a superplasticizer, Coll. tr. Chemical additives for concrete. pp. 119126, (1987)

5. Makhamataliev E.M. On a new strategy of application of the polystructural theory of composite building materials in research on improving the technology of filled concrete. Scientific, Proceedings of TASI, pp. 34-37. Tashkent, (2008)

6. Makhamataliev E.M. Concrete on an activated binder and with an ash filler, Sciences, p. 23. Tashkent (1993)

7. Kim K.N., Yazonkin V.I., Babaev V.A. Rheological properties of a concrete mixture with additives of superplasticizers, M., Betones with effective superplasticizers, NIIZhB, 1989 - $54 \mathrm{p}$.

8. Kim K.N. Methods for studying the rheological properties of concrete mix, M., NIIZhB, vol. 29, 1987 - P 2-16.

9. Goldenberg LB Influence of TPP ash additives on the main properties of fine-grained concrete // Concrete and reinforced concrete, 1987. - №1 - p. 15-17.

10. Ramachandran V. Additives to concrete, A reference guide, M: Stroyizdat, p.575, (1988)

11. The use of superplasticizers in concrete. Survey information. - VNIIMS Gosstroy USSR, p. 58 (1982)

12. Bazhenov Yu.M. High-strength concrete with chemical additives, concrete and reinforced concrete, 8 , pp. 29-31, (1977)

13. Shaumarov S.S., Adilhodzhayev A.I., Kondrazhenko V.I. Experimental research of structural organization of heat-insulating structural building materials for energy efficient buildings, XXII International Scientific Conference on Advanced In Civil Engineering, Construction the formation of living environment, pp. 1-7, (2019)

14. Gorchakov G.L., Alimov L.A., Voronin V.V., Uruev V.M. Instrument and method for establishing the rheological characteristics of concrete mixtures Rheology of concrete mixes and its technological problems. 252 p. Riga, (1989)

15. Volarovich M.P. Investigation of the rheological properties of dispersed systems. Colloid journal, 16 (3), pp. 20-(1984)

16. Turgunbaev U.Dj., Umirova M. On the technology of production of reinforced concrete sleepers by heating concrete at low temperatures, Bulletin of TashIIT, Special issue, pp. 109-115, (2020)

17. Solomatov V.I. Elements of the general theory of composite building materials, Izvestiya Vuzov, Construction and architecture, 12, pp. 61-70, 1980

18. Leshinsky M.V. On the use of fly ash in concretes. Concrete and reinforced concrete, № 1, pp. 19-21. 1987.

19. Rebinder P.A. Surfactants., p. 46, Moscow: Znanie (1971)

20. Rebinder P.A. Physicochemical mechanics of dispersed structures. p. 356 M, Nauka, (1966)

21. Solomatov V.I., Vyrovoy V.N., Khokhrina E.N. Influence of fillers on the kinetics of structure formation of cement compositions, Composite building materials using industrial waste, pp. 25-27, October 15-16, Seminar, Penza, (1984) 